DOI: 10.34015/2523-4552.2019.1.12

удк 343.9

Кузнецов М. Г., аспірант кафедри управління безпеки, правоохоронної та антикорупційної діяльності Міжрегіональної Академії управління персоналом

\title{
ВІКТИМОЛОГІЧНИЙ ПОРТРЕТ ЖЕРТВИ ДОМАШНЬОГО НАСИЛЬСТВА, ЩО Є НЕБЕЗПЕЧНИМ ДЛЯ ЖИТТЯ
}

У статті розкрито віктимологічний портрет жертви домашнього насильства, що $\epsilon$ небезпечним для життя. Віктимологічний портрет жертви подано через їі стать, вік, сімейний стан, освіту, соціальний стан і рід занять, особливості кримінально-правової характеристики, морально-психологічні напрями, фізичне та психічне здоров'я. Також визначено роль уживання жертвою алкогольних напоїв при вчиненні стосовно неї домашнього насильства, що $\epsilon$ небезпечним для життя.

Ключові слова: домашнє насильство; жертва; віктимологічний портрет; кваліфіковане убивство; умисне вбивство; тяжкі тілесні ушкодження.

В статье раскрыт виктимологический портрет жертвы домашнего насилия, опасного для жизни. Виктимологический портрет жертвы раскрыт через такие признаки: пол, возраст, семейное положение, образование, социальное положение и род занятий, особенности уголовно-правовой характеристики, морально-психологические направление, физическое и психическое здоровье. Также определена роль употребления жертвой алкогольных напитков при совершении в отношении нее домашнего насилия, опасного для жизни.

Ключевые слова: домашнее насилие; жертва; виктимологический портрет; квалифицированное убийство; умышленное убийство; тяжкие телесные повреждения.

Постановка проблеми. Безумовно, насильство в сім'ї - результат усвідомлених дій особи, яка його вчиняє. Воно підкріплене агресією та бажанням завдати шкоди, а не прагненням розв'язати побутовий кон $\phi$ лікт шляхом примирення.

Для пізнання генезису будьякого злочинного посягання, зокрема і домашнього насильства, недостатньо обмежитися вивченням особистості лише злочинця, оскільки відомо, що в ряді випадків остаточне прийн- яття рішення про вчинення тяжкого злочину проти особи багато в чому залежить від поведінки потерпілого. У зв'язку з цим тільки з урахуванням особи і поведінки потерпілого можна вирішити низку питань, зокрема: найбільш повно з'ясувати детермінанти злочинної поведінки, розкрити домінантні форми конфліктної взаємодії потерпілих і злочинців, що передували злочинному посяганню, проаналізувати їх вплив на формування готовності винних до вчинення 
злочину та виробити заходи запобігання злочинам зазначеної категорії.

Указана проблема як ніколи актуальна в Україні, де щодня фіксують близько 348 випадків домашнього насильства, а за рік реальна кількість випадків насильства в сім'ї становить понад півтора мільйони. При цьому, у зв'язку з високою латентністю злочинів зазначеної категоpiï, дослідження насильства в сім'ї, що $\epsilon$ небезпечним для життя, видається найбільш яскравою основою для відображення реальної жахливої картини насильства в сім'ї.

Постановка завдання. Мета статті - визначити віктимологічний портрет жертви домашнього насильства, що $є$ небезпечним для життя.

Виклад основного матеріалу. Особистість жертви в акті насильства $\epsilon$ окремою важливою кримінологічною проблемою. Зокрема, I. А. Петін вважає, що поведінка жертви визначається системою самопокарання, яка керується підсвідомістю. Основним елементом самопокарання в цьому випадку $є$ почуття провини. Сприйняття потерпілим злочинного насильства як утілення неминучості покарання за поведінку загалом має винятково важливе кримінологічне та кримінально-правове значення для запобігання насильницькій злочинності [1, с. 267].

Дуже важливим і кримінологічно значущим чинником $є$ характер відносин між потерпілими та злочинцями, їх соціально-побутові зв'язки на момент учинення злочину. Крім того, установлено, що чим ближчий зв'язок (за ступенем споріднення, інтенсивністю розвитку, тривалістю тощо) між потерпілим та злочинцем, тим вищою $є$ ймовірність стати жертвою вбивства.
Це спостереження підтверджується й детальнішим аналізом Л. А. Франком відносин між жертвами й убивцями в різних поведінкових ситуаціях жертви. Виявилося, зокрема, що дві третини загиблих становили дуже близькі і знайомі особи, які своєю негативною поведінкою створили криміногенну ситуацію та багато в чому визначили їі результат; з іншого боку, лише 30 \% загиблих, які не були знайомі зі злочинцями, своєю поведінкою ніяк не впливали на розвиток небезпечної ситуації: ці особи найчастіше ставали жертвами вбивства 3 хуліганських мотивів [2, с. 44].

Нами проведено анкетування 115 потерпілих від домашнього насильства в Дніпропетровській, Київській, Львівській, Полтавській, Черкаській, Чернігівській областях. Кримінологічна характеристика особистості потерпілого, як і особистості злочинця, вивчалася за сукупністю соціально-демографічних, кримінально-правових і морально-психологічних ознак.

За статтю більшість потерпілих від умисних убивств у сімейнопобутовій сфері - жінки (68,3%), решта $(31,7 \%)$ - чоловіки. Серед потерпілих від кваліфікованих убивств і тяжких тілесних ушкоджень дещо переважають чоловіки $\quad(54,4 \%$ та $53,1 \%$ відповідно), решта (45,6 \% та 46,9 \% відповідно) - жінки. Для порівняння: за даними окремих вибіркових кримінологічних досліджень, що проводилися понад 40 років тому (1975-1977 рр.) у контингенті жертв умисних убивств чоловіки склали $57 \%$, а жінки - $43 \%$ [3, с. 24].

Домінування серед потерпілих від умисних убивств жінок пояснюється тим, що вбивства більше тяжі- 
ють до сімейної сфери. В орбіті сімейних взаємин виникають криміногенні конфлікти, у яких, як правило, саме жінка виступає однією зі сторін протистояння. Разом із тим жінки переважно ініціюють подібні зіткнення, оскільки вони прагнуть змінити поведінку та статус чоловіка $[4$, c. 28]. При цьому їх дії нерідко характеризуються правомірним змістом, але зовні виражаються в образливій для злочинця формі [5, с. 49]. Головним чином, це різні докори, образи, приниження на адресу майбутніх злочинців. До цього слід додати, що поведінка жінок у сімейнопобутовій сфері дедалі частіше має необачний, ризикований, аморальний, провокаційний характер. Усі ці обставини виступають потужним подразником чоловічої агресивності. Чоловіки, використовуючи свою фізичну перевагу, нерідко самостверджуються, зганяють гнів, невдоволення і роздратування, що акумулюються роками, на більш слабких i незахищених жінках.

Структурний розподіл жертв від домашнього насильства, що $\epsilon$ небезпечним для життя, за статтю виглядає так:

- жінки: дружина (співмешканка) - кваліфіковані вбивства $(51,7 \%)$, умисні вбивства $(29,9 \%)$, тяжкі тілесні ушкодження $(34,5 \%) ;$ мати (сестра) - 7,5, 7 і 4,4 \% відповідно; донька, баба, теща - 5, 5,4 і 2,9 \% відповідно; коханка, приятелька, сусідка та інші особи - 4,1, 12,1 і 5,1% відповідно;

- чоловіки: чоловік (співмешканець) - 15,8, 13,1 і 9,9 \%, відповідно; син (брат) - 8,8, 10,5 і 16,8 \% відповідно; приятель, знайомий, сусід та інші особи - 21, 8,1 і 26,4 \% відповідHo.
Як вбачається із наведеного, більшість злочинів учинено стосовно членів сім'ї та близьких родичів, 3 якими у винних неодноразово виникали криміногенні конфлікти. При цьому нерідко злочинці характеризуються позитивно, а поведінка потерпілих мала неправомірний, провокаційний характер. Реакція обвинувачених виникала негайно у відповідь на напад, або ж злочинці здійснювали посягання на випередження, прагнучи таким чином нейтралізувати агресивність жертви.

За віковими показниками у структурі потерпілих найбільше осіб віком 30-50 років: кваліфіковані вбивства (36,8\%), умисні вбивства (41,3\%), тяжкі тілесні ушкодження (53,6 \%). Друге місце посідає старша вікова група потерпілих (51 рік і старші) - 29,8, 37,7 і 24,1 \% осіб відповідно. За ними йдуть потерпілі від 14 до 29 років - 28,1, 19,5 і 21,5 \% відповідно. Решта жертв були молодшого віку - 5,3, 1,5 і 0,8 \% відповідно. Для порівняння: за даними деяких зарубіжних кримінологів, 40,7 \% жертв умисних убивств мали вік 2545 років, 23,7\% - старші 60 років, $21,5 \%$ потерпілих були у віці 4560 років [6, с. 96$]$.

За сімейним станом більшість потерпілих від умисних убивств і тяжких тілесних ушкоджень були одружені або перебували у фактичному шлюбі - 68,4 \% і 64,9 \%. Зменшується цей показник щодо потерпілих від кваліфікованих убивств - 50,9\%. Серед неодружених і розлучених: кваліфіковані вбивства - 40,4\%, умисні вбивства - 27,1\%, тяжкі тілесні ушкодження - 27,4\%. Як бачимо, більш «уразливою» $є$ одружена категорія потерпілих. Це пояснюється тим, що вони більше пов'язані зі зло- 
чинцем періодичними, побутоводозвільними зв'язками, які виникали, як правило, на грунті спільного вживання спиртних напоїв.

Інший сімейний стан установлено для кваліфікованих убивств $10,6 \%$, умисних убивств - 4,5 \%, тяжких тілесних ушкоджень - 8,7 \% потерпілих. Це - удови (удівці), особи, які одружені, але не проживають із сім'єю.

Загалом суб'єкти насильницьких злочинів характеризуються невисоким рівнем освіти. Не $є$ винятком і суб'єкти насильницьких злочинів у сім'ї. Як з'ясувалося, таке становище характерне і для потерпілих від цих злочинів. Зокрема, у більшості випадків останні мали базову середню та повну середню освіту у 64,8 \% кваліфікованих убивств, 76,5 \% умисних убивств, 68,9\% тяжких тілесних ушкоджень. Середня спеціальна освіта зафіксована у 17,6, 13,5 і 17,9\% потерпілих. Частка осіб із базовою вищою i повною вищою освітою складає відповідно 1,7, 1,5 і 3,4\%. Проте значно більше потерпілих із освітнім рівнем декілька класів - 10,6, 6,5 і 6,8 \%, а також тих, які взагалі не мали освіти, - 5,3, 2 і 3 \% відповідно.

Видається, що деяке пониження освітнього рівня потерпілих порівняно зі злочинцями певною мірою підвищувало їх індивідуальну віктимність [7, с. 192]. Адже відомо, що люди 3 низьким освітнім і культурним рівнем більш грубі, нестримані, нахабніші та частіше створюють конфліктні ситуації, під час яких не можуть правильно оцінити характер своєї поведінки і передбачити подальші дії.

Саме така позиція, що прямо пов'язує рівень освіти з підвищеною віктимністю, відстоюється Д. В. Рів- маном, який вказує, що, по-перше, особи малограмотні частіше вчиняють злочини насильницького характеру, а отже і частіше викликають на себе відповідну реакцію, що призводить до заподіяння їм шкоди; подруге, низький освітній рівень нерідко стає причиною того, що особа не спроможна оцінити обстановку й можливі наслідки поведінки, а відтак не виявляє бажання звернутися за захистом, не знає компетентних органів, які можуть надати захист, тощо $[8$, с. 27]. Тим часом самостійна роль освітнього рівня як чинника підвищеної віктимності, на нашу думку, перебільшена. Він проявляється не прямо, а опосередковано через цілу низку різнорівневих зв'язків в адекватному або неадекватному сприйнятті ситуації.

За соціальним станом і родом занять у структурі потерпілих більшість осіб - непрацюючі та безробітні: кваліфіковані вбивства (64,9 \%), умисні вбивства (61\%), тяжкі тілесні ушкодження (53 \%). На другому місці йдуть некваліфіковані або малокваліфіковані робітники (сільські робітники) державних, колективних i приватних підприємств, установ, організацій - відповідно 21, 22 і 33 \%. Дуже низький коефіцієнт державних службовців - 1,5 і 2,6 \%. На частку учнів шкіл, ПТУ, ВНЗ припадає відповідно 5,2 і 0,4 \% потерпілих. Не містилося необхідних відомостей у матеріалах наглядових проваджень щодо 8,9, 15,5 і 11 \% потерпілих.

Домінування серед потерпілих осіб, не зайнятих суспільно корисною працею, необхідно розцінювати як результат дії принаймні трьох головних чинників: сучасна загальносуспільна проблема працевлаштування; низький освітній і кваліфіка- 
ційний рівень, що не дозволяє конкурувати на ринку праці; небажання працевлаштовуватися, що свідчить про схильність до ведення паразитичного способу життя. Незайнятість тягне низку негативних наслідків, про які йшлося раніше, а отже, є певним віктимогенним чинником.

За особливостями кримінальноправової характеристики особи потерпілого спостерігаємо таку ситуацію. Більшість потерпілих протиправних діянь раніше не вчиняли: 75,6, 71,4 і 71 \% відповідно. Притягалися до кримінальної відповідальності відповідно 19,2, 11 і 12,9 \% потерпілих. Щодо решти осіб необхідна інформація в матеріалах наглядових проваджень відсутня. Потерпілі скоювали здебільшого корисливі, корисливо-насильницькі злочини, злочини проти громадського порядку та ін. Крім того, 21, 12,5 і 15,4 \% потерпілих попередньо притягувалися до адміністративної відповідальності. Решта осіб не притягувалася до юридичної відповідальності або ж у матеріалах наглядових проваджень не містилося необхідних відомостей.

Отже, певна частина потерпілих до вчинення проти них протиправного посягання мали відповідний досвід негативної протиправної або злочинної діяльності, що, безумовно, наклало негативний відбиток на характер їх поведінки та підвищувало їх віктимність.

Не можна оминути тему пияцтва у контексті нашого дослідження. Безумовно, алкогольне сп'яніння впливає на поведінку потерпілих, знижує здатність потенційної жертви правильно оцінити ситуацію, можливості опору; у стані сп'яніння частіше й простіше зав'язуються випадкові знайомства, потерпілі часті- ше стають ініціаторами сварок і бійок, провокуючи своїми діями тих, хто, зрештою, став убивцею. Так, за результатами нашого дослідження при кваліфікованих убивствах $58 \%$ потерпілих на момент учинення злочину перебували у стані алкогольного сп'яніння, при умисних убивствах - 55,3 \%, заподіянні тяжких тілесних ушкоджень - 62,2 \%. Досить схожі цифри виявив О.Є. Михайлов, за даними дослідження якого цей показник становить $61,6 \%$ [9, с. 17].

Разом із тим встановлено, що відповідно 43,9, 57,4 і 59,1 \% потерпілих ще задовго до злочинного посягання вживали спиртні напої разом із майбутнім убивцею або особою, яка згодом завдасть тяжкі тілесні ушкодження. Причому 8,75, 14 i 10,9\% потерпілих робили це систематично, решта - періодично або безпосередньо в день учинення злочину. Відомо, що на осіб, які перебувають у нетверезому стані, в силу їх послабленого опору легше чинити будь-яке злочинне посягання $\mathrm{y}$ зв'язку із в цілому підвищеною загальною віктимністю [9, с. 72]. Разом із тим зростає спеціальна віктимність, тому що потерпілі поводяться нахабно і зухвало, втрачають контроль над власною поведінкою, часто ініціюють сварки та бійки. Крім того, безпорадність і безсоромність особи через їі сп'яніння, як правило, збуджує агресивність і жорстокість злочинця.

Очевидно, слід погодитися 3 М.Х.Сафіуліним у тому, що єдина для тих та інших субкультура і маргінальне середовище, де процвітають пияцтво, сварки і скандали, сприяє частішому виникненню таких конфліктів, коли потенційного потерпілого не можна заздалегідь відріз- 
нити від потенційного злочинця, коли лише випадок вирішує, хто стане жертвою, а хто - убивцею $[11$, c. 15$]$.

Вивчення особи потерпілого за морально-психологічним напрямом дало такі результати. Насамперед, звертає на себе увагу алкогольна обтяженість, що має досить поширений характер. На грунті зловживання потерпілими спиртними напоями 3 різних незначних для тверезої людини приводів з потенційним злочинцем виникали численні конфлікти, що розв'язувалися шляхом фізичного впливу, нерідко взаємного, тобто відбувалися своєрідні «репетиції» майбутнього злочину. В окремих літературних джерелах відзначалося, що значна частина побутових злочинів учиняється проти осіб, які ведуть аморальний або паразитичний спосіб життя [12, с. 26].

Нами встановлено, що 21,1, 20,1 і 13,5 \% потерпілих вели зазначений спосіб життя. Аморальна поведінка більше властива жінкам. Як правило, вона виявлялася в сексуальній розпусті, подружніх зрадах, створенні різних інтимних інтриг, на що свого часу звертав увагу В. В. Вандишев [13, с. 8]. Соціальний паразитизм потерпілих накладав специфічний відбиток на їх морально-психологічний образ i, крім того, викликав огиду і ненависть у злочинців.

У процесі дослідження вдалося встановити деякі дані щодо фізичного та психічного стану здоров'я потерпілих. Зокрема, 14, 16,5 і 16,1 \% із них мали хронічні (соматичні) захворювання (гіпертонія, стенокардія, атеросклероз, різні фізичні вади тощо). Проте переважна більшість потерпілих не мала жодних фізичних захво- рювань або ж у матеріалах наглядових проваджень не було зазначеної інформації $(86,83,5$ і 83,9 \% відповідно). Що стосується психічного стану здоров'я, то в переважній більшості випадків не було виявлено жодних психічних патологій або в наглядових провадженнях були відсутні необхідні відомості (відповідно 89,5, 92 і 88,6 \%). Уважаємо, що на ці показники вплинуло те, що більшість потерпілих загинули, а тому психологічнопсихіатричні експертизи не проводилися. Виняток становлять потерпілі від тяжких тілесних ушкоджень, які залишилися живими. У них під час відповідних експертиз установлено деякі аномалії психіки (11,5 \%), зокрема хронічний алкоголізм (4,8 \%), наркоманія $(0,4 \%)$, епілепсія, шизофренія (1,1\%), олігофренія (1,8\%), інші $(3,4 \%) .3$ огляду на це можна припустити, що певна частина потерпілих із психічними аномаліями перейшли до розряду латентних.

Отже, наявність деяких фізичних і психічних захворювань у певної частини потерпілих загалом підвищувала їх віктимність, оскільки під їх впливом поведінка останніх набувала агресивного або яскраво провокаційного характеру. Разом із тим психофізичні вади значно зменшували можливість потерпілих уникнути злочинного посягання, чинити гідний опір, рятуватися втечею чи звернутися за допомогою до компетентних органів або окремих осіб.

Підбиваючи підсумок наведених характеристик особистості потерпілого, необхідно відзначити, що в кожній конкретній ситуації пріоритет одного з віктимологічних чинників визначає симбіоз особистісних i поведінкових ознак, що характеризують потерпілого від домашнього 
насильства. Їх вичленовування й оцінка мають не тільки важливе значення для кваліфікації вчиненого та визначення міри покарання винного, а й для вжиття заходів загального та індивідуального запобігання з метою зниження рівня домашнього насильства.

\section{Список використаних джерел}

1. Петин И. А. Механизм преступного насилия. Санкт-Петербург, 2004. 349 с.

2. Франк Л. В. Виктимология и виктимность (Об одном новом направлении в теории и практике борьбы с преступностью). Душанбе, 1972.143 с.

3. Коновалов В. П. Изучение потерпевших от преступлений с целью совершенствования профилактики правонарушений. Москва, 2010. 72 с.

4. Шинкаренко О. Д. Психологічні особливості жертв подружнього насильства. Практична психологія та соціальна робота. 2000. № 3. С. 25-28.

5. Блага А. Б. Насильство в сім'ї (кримінологічний аналіз та запобігання): монографія. Харків, 2014. 360 с.

6. Первякова И. К. Женщина - жертва преступлений (по материалам Нижегородской области). Социс. 2000. № 9. С. 96-97.

7. Головкін Б. М. Потерпілий у сімейно-побутових тяжких насильницьких злочинах проти особи. Конституція - основа державно-правового будівництва і соціального розвитку України: тези доп. та наук. повідом. учас. наук. конф. молод. учених (м. Харків, 30 черв. 2001 р.) / За ред. М. І. Панова. Харків, 2001. С. 191-194.

8. Ривман Д. В. Криминальная виктимология. Санкт-Петербург, 2002. 304 с.

9. Мірошніченко Т. О. Загальна характеристика рівнів віктимологічної профілактики корисливо-насильницьких злочинів. Європейські перспективи. 2016. Вип. 2. С. 70-74.

10.Жарій В., Михайлов О. Алкогольне сп'яніння як фактор віктимності потерпілих від злочинів. Радянське право. 1988. № 3. С. 62-64.

11. Сафиуллин Н. Х. Виктимное поведение несовершеннолетних и совершаемые против них насильственные преступления: автореф. дисс. ... канд. юрид. наук: 12.00.08. Москва, 1995. 24 с.

12. Романова Л. И. Паразитический образ жизни и проблемы виктимологии. $\mathrm{Bu}$ ктимологические проблемы борьбы с преступностью : сб. науч. тр. Иркутск, 1988. C. 22-31.

13. Вандышев В. В. Виктимология: что это такое? Ленинград, 1978. 19 с.

\section{References}

1. Petin, I. A. (2004). Mehanizm prestupnogo nasiliya. Sankt-Peterburg [in Russian].

2. Frank, L. V. (1972). Viktimologiya i viktimnost (Ob odnom novom napravlenii v teorii i praktike borby s prestupnostyu). Dushanbe [in Russian].

3. Konovalov, V. P. (2010). Izuchenie poterpevshih ot prestuplenij $s$ celyu sovershenstvovaniya profilaktiki pravonarushenij. Moskva [in Russian].

4. Shinkarenko, O. D. (2000). Psihologichni osoblivosti zhertv podruzhnogo nasilstva. Praktichna psihologiya ta socialna robota. 3, 25-28 [in Ukrainian].

5. Blaga, A. B. (2014). Nasilstvo v sim'yi (kriminologichnij analiz ta zapobigannya). Harkiv [in Ukrainian].

6. Pervyakova, I. K. (2000). Zhenshina - zhertva prestuplenij (po materialam Nizhegorodskoj oblasti). Socis. 9, 96-97 [in Russian]. 
7. Golovkin, B. M. (2001). Poterpilij u simejno-pobutovih tyazhkih nasilnickih zlochinah proti osobi, Konstituciya - osnova derzhavno-pravovogo budivnictva i socialnogo rozvitku Ukrayini: tezi dop. ta nauk. povidom. uchas. nauk. konf. molod. uchenih (m. Harkiv, 30 cherv. 2001 r.) / Za red. M. I. Panova. Harkiv [in Ukrainian].

8. Rivman, D. V. (2002). Kriminalnaya viktimologiya. Sankt-Peterburg [in Russian].

9. Miroshnichenko, T. O. (2016). Zagalna harakteristika rivniv viktimologichnoyi profilaktiki korislivo-nasilnickih zlochiniv. Yevropejski perspektivi. 2, 70-74 [in Ukrainian].

10.Zharij, V., Mihajlov, O. (1988). Alkogolne sp'yaninnya yak faktor viktimnosti poterpilih vid zlochiniv. Radyanske pravo. 3, 62-64 [in Ukrainian].

11. Safiullin, N. X. (1995). Viktimnoe povedenie nesovershennoletnih i sovershaemye protiv nih nasilstvennye prestupleniya (Avtoref. diss. ... kand. yurid. Nauk). Moskva [in Russian].

12. Romanova, L. I. (1988). Paraziticheskij obraz zhizni i problemy viktimologii, Viktimologicheskie problemy borby s prestupnostyu: sb. nauch. tr. Irkutsk [in Russian].

13.Vandyshev, V. V. (1978). Viktimologiya: chto eto takoe? Leningrad [in Russian].

M. Kuznetsov, Postgraduate student of the Security, Law Enforcement and Anti-Corruption Activity Chair of the Interregional Academyof Personnel Management

\section{Victimological portrait of the victim of the domestic violence, which is dan- gerous for life}

The article contains the victimological portrait of a victim of the domestic violence, which is dangerous for life. Victimological portrait of a victim is considered taking into consideration the gender, age, marital status, education, social status and occupation, features of the criminal-legal characteristics, moral and psychological directions, physical and mental health. Besides, the role of the alcohol victimization in the domestic violence, which is dangerous to life, is defined.

The above mentioned problem is more than ever topical in Ukraine, where about 350 cases of domestic violence are recorded daily. During one year the actual number of the domestic violence cases is more than 1.5 million. At the same time, due to the high latency of that category of crimes, the research concerning the domestic violence, which is dangerous to life, seems to be the most vivid basis for the reflection of the real horrible picture of the domestic violence in Ukraine.

The article states that the physical and mental diseases of the victims increase their victimity, because under such influence, the behavior of the latter acquires the aggressive or vividly provocative character. At the same time, psychophysical defects significantly reduce the victim's ability to avoid criminal offenses, to resist, or escape or to seek help from the competent authorities or other persons.

It is cleared up that some victims of the illegal encroachments have their own negative experience of the illegal or criminal activity, which impacts negatively on their behavior and increases their victimization.

Summing up the provided characteristics of the victim's personality, it should be noted that in each particular situation, the priority of one of the victimological factors determines the symbiosis of the personality and the behavioral characteristics of 
the domestic violence victim. Their assessment are not only important for the qualification of the offenders, imposing them the proper punishment, but also for taking the general and personal prevention measures in order to reduce the increasing level of the domestic violence.

Keyword: domestic violence; victim; victimological portrait; qualified murderer; deliberate murder; grave injuries.

Надійшла до редакції 04.03.2019 